УДК [378. 091.212:7] - 047.22

DOI: https://doi.org/10.35619/iiu.v0i9.145

Дзюбишина Наталія

кандидат педагогічних наук, доцент, декан художньо-педагогічного факультету Рівненського державного гуманітарного університету,

м. Рівне, Україна

ORCID : 0000-0002-2704-8157

e-mail: natalia_dziubyshyna@ukr.net

\title{
ПЕДАГОГІЧНІ УМОВИ ФОРМУВАННЯ ДОСЛІДНИЦЬКОЇ КОМПЕТЕНТНОСТІ У СТУДЕНТІВ ХУДОЖНЬО-ПЕДАГОГІЧНОГО ФАКУЛЬТЕТУ
}

\begin{abstract}
Анотація. У статті актуалізовано проблему формування у студентів художньо-педагогічного факультету дослідницької компетентності. Розкрито сутність і значущість дослідницької компетентності, виділено складові компетентності дослідницької компетентності й обгрунтовано їхній зміст. Виокремлено педагогічні умови підвищення ефективності процесу формування дослідницької компетентності майбутніх фахівців художньо-педагогічних спеціальностей, як-то: цілеспрямоване формування мотиваційно-ціннісної спрямованості особистості на продуктивну і творчу діяльність дослідницького характеру, логіка розгортання якого реалізується у закладі вищої освіти 3 формування мотивів та потреб майбутнього спеціаліста у сфері художньопедагогічної дії, а згодом трансформуються у систему ціннісного ставлення до науково-дослідницької діяльності як невід'ємної складової продуктивної професійної діяльності; змістово-процесуальне та технологічне забезпечення науково-дослідницької діяльності студентів, яке уможливлює розвиток у них операційних, організаційні, практичних і комунікативних знань, умінь, практичних навичок і способів мислення в умовах впровадження спеціально сконструйованого навчального курсу, різноманітних форм та методів активної педагогічної взаємодії; організація цілеспрямованої продуктивної діяльності студентів 3 достатньо грунтовного оволодіння фаховими знаннями (диференціюються залежно від напряму мистецької діяльності і визначаються стандартами вищої освіти), у якій формуються необхідні для майбутньої професії особистісні якості (ініціативність, самостійність, відповідальність, наполегливість); створення інноваційнорефлексивного середовища для формування особистісної і професійної рефлексії, яка уможливлює самоаналіз та аналіз професійної діяльності, самооцінку й оцінку іiі ефективності.
\end{abstract}

Ключові слова: дослідницька компетентність, складові дослідницької компетентності, педагогічні умови, студенти художньо-педагогічного факультету.

Постановка проблеми. Розгортання демократичних перетворень в Україні, стрімкі соціально-економічні трансформації в усіх сферах життєдіяльності сучасної людини, громади і суспільства вимагають спеціалістів, здатних до конструктивної особистісної та професійної взаємодії, швидкої зміни способів, форм і технологій професійної діяльності 3 урахуванням вимог інформаційного суспільства та суспільно-державних вимог до виховання і розвитку зростаючої особистості. Згадані вимоги актуалізують 
проблему розгортання наукових розвідок у сфері підвищення якості вищої педагогічної освіти на підставі запровадження в освітній процес вищої школи компетентнісного підходу, який задає модель випускника зі сформованими вміннями і досвідом практичного вирішення професійних завдань та здатністю до особистісного й професійного саморозвитку впродовж життя.

Реалізація компетентнісного підходу у фаховій підготовці студентів художньо-педагогічного факультету передбачає формування у них дослідницької компетентності, яка $\epsilon$ складовою загального переліку результатів навчання і компетентностей сучасного випускника закладу вищої педагогічної освіти. Водночас відзначимо, що дослідницька компетентність у моделі випускника мистецьких спеціальностей $є$ джерелом його продуктивної професійної діяльності в майбутньому, мотиваційною основою безперервного професійного самовдосконалення. Саме тому, на нашу думку, й актуалізується нині проблема підвищення ефективності цього процесу за рахунок розроблення дієвих педагогічних умов формування дослідницької компетентності у студентів художньо-педагогічного факультету.

Аналіз останніх досліджень 3 проблеми. Проблеми формування у студентів дослідницької компетентності достатньо грунтовно розкриті в наукових працях А. Деркача, М. Голованя, В. Яценка (обгрунтовано сутність i зміст дослідницької компетентності в структурі професійної компетентності педагога) (Головань та Яценко, 2012), Ю. Волинець (розкрито особливості дослідницької компетентності майбутніх вихователів дошкільних навчальних закладів), Т. Ваколя (визначено специфіку дослідницької компетентності вчителя початкових класів), Г. Омеляненко (розкрито специфіку дослідницької компетентності фахівців фізичної культури і спорту), Л. Бурчак (визначено специфіку формування дослідницької компетентності в системі вищої освіти майбутнього вчителя хіміі). Також проведені окремі дослідження 3 питань формування дослідницької компетентності майбутніх інженерів у процесі викладання навчальних дисциплін природничо-наукової підготовки (С. Бєлкіна), майбутнього інженера-педагога (М. Архипова), а також майбутніх викладачів закладів вищої освіти в умовах магістратури (Л. Бондаренко).

Крім того, нині вже ні в кого не виникає сумніву та загальноприйнятою $є$ теза про те (М. Архипова, С. Балашова, Л. Бондаренко, Л. Бурчак, С. Бєлкіна, Т. Ваколя, Ю. Волинець, М. Головань, А. Деркач, Н. Недодатко, Г. Омеляненко, О. Рогозіна, О. Миргородська, М. Фалько та інші), що дослідницька компетентність є складовою базових компетентностей сучасного випускника закладу вищої педагогічної освіти, яка формується у процесі спеціально організованої науково-пошукової, науково-дослідницької і проектно-технологічної діяльності в умовах рефлексивного інноваційного середовища вищого педагогічного закладу освіти (Балашова, 2000; Рогозіна, 2007).

Мета статті - розкрити сутність та зміст поняття «дослідницька компетентність», виокремити іiі складові, обгрунтувати педагогічні умови підвищення ефективності процесу формування дослідницької компетентності у студентів художньо-педагогічного факультету.

Виклад основного матеріалу дослідження. Дослідницька компетентність студентів художньо-педагогічного факультету, на нашу думку, $\epsilon$ динамічною комбінацією сформованих у них знань, умінь і практичних навичок науково-дослідницької діяльності, способів мислення, професійних, 
світоглядних і морально-етичних цінностей, які визначають їхню здатність самостійно і продуктивно вирішувати проблемні та нестандартні практичні професійні завдання на підставі безперервної самозміни і професійного самовдосконалення.

Закцентуємо увагу, що у згаданому вище визначенні система світоглядних і морально-етичних цінностей утворює мотиваційно-ціннісну основу спрямованості студента до науково-дослідницької діяльності. Цей складник є невичерпним джерелом прагнення особистості до особистісної самозміни i професійного самовдосконалення, накопичення досвіду розв'язання щоденних практичних задач. Тому перша група педагогічних умов підвищення ефективності процесу формування у студентів спеціальностей художньо-педагогічного факультету й має бути спрямована на формування мотиваційно-ціннісного орієнтиру особистості на продуктивну i творчу діяльність дослідницького характеру. Логіка розгортання цього процесу реалізується через створення у закладі вищої освіти дослідницького середовища (наукові студентські конференції, презентація наукових досягнень студентів, студентські наукові товариства тощо), використання форм і методів педагогічної взаємодії (евристичний пошук, навчально-рольові та ділові ігри, проблемні семінари, пошукова самостійна робота та інші), які формують спершу мотиви та потреби майбутнього спеціаліста у сфері художньопедагогічної дії, а згодом трансформуються у систему ціннісного ставлення до науково-дослідницької діяльності як невід'ємної складової продуктивної професійної діяльності нині і в майбутньому.

Друга група педагогічних умов має визначати й забезпечувати достатній рівень знань, умінь i практичних навичок для здійснення науководослідницької діяльності (актуалізація дослідницького протиріччя, формулювання мети, постановка цілей, розроблення етапів, обгрунтування $\mathrm{i}$ вибір засобів досягнення цілей, розроблення програми дій, оцінка ефективності педагогічного впливу та коригування, за потреби, формувальних впливів тощо), а також способів мислення (аналіз, синтез, узагальнення, виділення головного, систематизація, конкретизація). Динамічна комбінація згаданих вище знань, умінь, практичних навичок і способів мислення $\epsilon$ змістовопроцесуальною та технологічною складовою забезпечення науково-пошукової та науково-дослідницької діяльності, яка формується в процесі цілеспрямованого вивчення студентами змісту науково-дослідницької роботи (спеціально сконструйованого навчального курсу як-от, «Основи науковопедагогічних досліджень», «Методологія та методи наукових досліджень»), іiі планування, організації, експериментування та узагальнення дослідницьких результатів, практичне впровадження під час практики, підготовки й оприлюднення результатів бакалаврського і магістерського дослідження.

3 метою розкриття змісту згаданого вище динамічного поєднання знань, умінь, практичних навичок і способів мислення звернемося до праць Ю. Волинець, яка на основі дослідження Н. Литовченка розподіляє їх на чотири групи, а саме:

операційні дослідницькі вміння, до яких відносяться розумові прийоми і операції, що застосовуються в дослідницькій діяльності (порівняння, аналіз і синтез, абстрагування та узагальнення, висунення гіпотези, співставлення та узагальнення й інші розумові операції); 
- організаційні дослідницькі вміння, що охоплюють застосування прийомів самоорганізації в науково-дослідній діяльності (планування науководослідної роботи, проведення самоаналізу та самоконтролю, регуляція своїх дій у процесі дослідницької діяльності);

- практичні дослідницькі вміння (опрацювання літературних джерел, проведення експериментальних досліджень, спостереження фактів, подій та обробка експериментальних даних спостережень, впровадження результатів у практичну діяльність);

- комунікативні дослідницькі вміння, необхідні для застосування прийомів співробітництва в процесі дослідницької діяльності, для здійснення взаємодопомоги, взаємоконтролю обговорення результатів. До комунікативних вченою віднесено також і дотримання корпоративної культури, вміння вести дискусію та обговорювати результати (Волинець, 2015, с. 104).

Отже, виділена нами друга педагогічна умова підвищення ефективності формування у студентів спеціальностей художньо-педагогічного факультету передбачає розвиток у них операційних, організаційні, практичних $\mathrm{i}$ комунікативних знань, умінь, практичних навичок і способів мислення, які виявляються у змістово-процесуальному та технологічному аспектах науководослідницької діяльності. Реалізується це в умовах сучасної вищої художньопедагогічної освіти через впровадження спеціально сконструйованого навчального курсу, різноманітних форм та методів активної педагогічної взаємодії (лекції, практичні та семінарські заняття, науково-дослідницькі проекти, дискусії, круглі столи, дослідницькі завдання 3 наступним обов'язковим обговоренням результатів, презентації й обговорення в режимі реального часу дослідницьких проблем 3 допомогою мережі Інтернет, соціальних мереж, форумів тощо).

Наступна група педагогічних умов спрямована на формування професійної складової дослідницької компетентності, яку утворюють особистісні якості (ініціативність, самостійність, відповідальність, наполегливість, тощо) i фахові знання (диференціюються залежно від художньо-педагогічної діяльності і визначаються стандартами вищої освіти). Саме ця група педагогічних умов $є$ надзвичайно важливою, оскільки завдяки цим умовам конкретизується зміст науково-дослідницької діяльності в контексті художньо-педагогічних спеціальностей, специфіка й особливості їхніх вимог до особистості і професіонала. Обгрунтуємо це твердження на кількох прикладах наукових розвідок вітчизняних учених мистецької галузі.

Сьогодні значний потенціал у підвищенні ефективності педагогічної діяльності вчителя музики, як стверджують Є. Проворова і Чжан Цзінцзін, має праксеологія, основними рисами якої $\epsilon$ раціональність, доцільність, оптимальність, творчість, ініціативність, вправність. Такий підхід увиразнює необхідність удосконалювати методичну підготовку майбутніх учителів музики до співацької діяльності як високодуховних, моральних i фахово компетентних особистостей, котрі покликані формувати ціннісні потреби, естетичні інтереси, ідеали і смаки учнів на кращих зразках українського i світового вокального мистецтва, вміють реалізувати навчальну, виховну та розвивальну функції, цілі, задачі, зміст, методи, засоби музичної освіти, що втілюється в наочних зразках творчого процесу взаємодії учнів з музичним мистецтвом та музичною культурою, здатні до неперервного професійного розвитку, саморозвитку. Праксеологічний підхід, доходять висновку вчені, дає 
можливість розробляти дієві моделі методичної підготовки майбутнього вчителя в умовах музично-педагогічних факультетів. Такі етапи методичної підготовки вчителя, як актуалізаційно-цільовий, концептуально-пізнавальний, організаційно-моделюючий, практично-діяльнісний, коригувальнорезультативний і педагогічні умови (спонукання студентів до креативного самовираження у співацькій та музично-педагогічній діяльності; вивчення навчальних дисциплін на засадах міжпредметної інтеграції; використання в педагогічній практиці форм, методів і засобів мистецьких інновацій, новаторства та самоосвіти, створення нових оригінальних методів навчання музики) забезпечують підвищення ефективності педагогічної діяльності сучасного вчителя музики (Проворова, 2017, с. 224-228).

Розглянемо також особливості професійної діяльності сучасного вчителя мистецьких дисциплін у системі загальної середньої освіти. Специфікою цієї освітньої галузі у початковій ланці нової української школи нині $є$ інтеграція змісту мистецьких навчальних предметів в один інтегрований курс «Мистецтво». Зміст цього інтегрованого навчального предмету передбачає конструювання й організацію такої умотивованої діяльності учнів молодших класів, в якій тісно переплітаються та інтегруються різні освітні предмети (музика, мистецтво, хореографія, технології та інші), форми (індивідуальна, парна, групова, колективна тощо) та способи навчальної діяльності (навчальноігрова, проектна, дослідницька, образотворча, сценічна, предметно-пошукова та інші) педагога та учнів, з обов'язковим акцентом на вирішення відповідно до вікового потенціалу зростаючої особистості практичних проблем. При цьому варто зважати також на те, що суттєво зростають вимоги до цього процесу через стрімке впровадження в освітній процес інформаційнокомунікаційних технологій, засобів мережі Інтернет, програмно-методичного забезпечення та наочності, яке модифікується, наповнюється і розширюється в режимі реального часу. Це вимагає від сучасного педагога мистецьких особистісних якостей (ними, на нашу думку, мають бути ініціативність, самостійність, відповідальність, наполегливість) i достатньо грунтовних фахових знань 3 музики, образотворчого мистецтва, хореографії, сценічного мистецтва й інших класичних і сучасних способів мистецької дії. Такі знання в різних педагогічних середовищах диференціюються залежно від напряму мистецької діяльності педагога.

I, нарешті, четверту групу педагогічних умов продуктивної дослідницької компетентності студентів спеціальностей художньо-педагогічного факультету формує педагогічна рефлексія, яка уможливлює самоаналіз та аналіз професійної діяльності (науково-пошукової, науково-дослідницької, проектнотехнологічної, практичної та інше), самооцінку й оцінку іiі ефективності. Реалізується згадана педагогічна умова через створення дієвого рефлексивного середовища, в якому особистісна і професійна рефлексія має стати дієвим механізмом самоуправління власною навчальною діяльністю студентів художньо-педагогічних спеціальностей. При цьому професійна рефлексія сприяє якісному зворотному зв'язку між ефективністю досягнення цілей навчання i виховання, підібраних способів діяльності та засобів, які іiі супроводжували, і тими цілями, що відповідали меті спеціально організованого художньо-педагогічного процесу. А особистісна рефлексія забезпечує осмислення майбутнім педагогом результатів своєї діяльності та задіяного особистісного потенціалу в цьому процесі, мотивує його до грунтовного 
аналізу власного професійного досвіду і якостей, які необхідні для значно ефективнішого конструювання й реалізації певного освітнього завдання в майбутньому.

Варто зазначити, що проблема рефлексії нині достатньо грунтовно розкрита в працях вітчизняних учених (М. Боришевський, В. Давидов, О. Зак, А. Карпов, І. Мельничук та інші), які розглядають іï як вкрай важливу у формуванні готовності майбутніх педагогів до професійної діяльності та досягнення у майбутньому особистісної й професійної досконалості.

Предметом дослідження педагогічної рефлексії стали праці М. Марусинець, І. Парфентієвої. У дослідженнях М. Марусинець педагогічна рефлексія $\epsilon$ необхідною і надзвичайно важливою складовою професійного успіху сучасного вчителя, яку вона визначає (за Г. Щедровицьким) як мислительну діяльність, спрямовану за допомогою мовних знаків на діяльність як на новий предмет самоаналізу. При цьому, на ії думку, розвинена здатність до рефлексії формується у студентів у процесі вирішення навчальних завдань, які вимагають загальних способів розв'язання певних ситуацій, засвоєння узагальнених способів дій у сфері наукових понять. 3 цього випливає, наголошує М. Марусинець, доцільність включення у процес формування професійної рефлексії таких навчальних завдань, що передбачають використання умінь аналізувати свої навчальні дії, порівнювати кілька способів навчальної роботи, розвивати здатність до самоконтролю та самооцінки власної діяльності. Вихідною умовою формування професійної рефлексії, вважає вчена, є створення належного рефлексивного середовища, що $є$ важливим чинником конструктивного впливу на процеси особистісного розвитку студента, в якому рефлексія має стати дієвим механізмом самоуправління власною навчальною діяльністю (Марусинець, 2012).

У дисертаційному дослідженні І. Парфентієвої з проблеми формування рефлексії у майбутніх учителів музики з'ясовано, що саме рефлексія забезпечує вихід 3 повного занурення у безпосередній процес життя для вироблення відповідного ставлення до нього. При цьому, на iіi думку, особливої гостроти згадана проблема набуває у період навчання у $3 \mathrm{BO}$, який $\epsilon$ найбільш суперечливим у розвитку особистості. Механізмом ускладнення, диференціації та інтеграції самосвідомості майбутніх учителів виступає особистісна рефлексія, що надає більше можливості осмислювати, аналізувати та пізнавати самих себе (Парфентієва, 2010, с. 7-8). Педагогічними умовами іiі ефективного поетапного (пізнавально-самоаналізуючий, цінніснорегулятивний, усвідомлено-творчий етапи) формування у процесі фахового становлення студентів інститутів мистецтв та музично-педагогічних факультетів педагогічних університетів, доходить висновку I. Парфентієва, є: створення атмосфери емоційної відкритості та творчої активності; забезпечення пріоритету практичної діяльності; актуалізація особистісного досвіду спілкування з мистецтвом (Парфентієва, 2010, с. 12-13).

Отже, зміст формування педагогічної рефлексії у закладі вищої освіти має спрямовуватися на розвиток професійної рефлексії, яка розкриває здатність педагога удосконалювати в майбутньому освітній процес, i особистісної, що мотивує особистість до неперервного навчання впродовж життя, грунтуючись на самоаналізі й адекватні професійні самооцінки. Створене для цієї мети інноваційно-рефлексивне середовище передбачає насичення аудиторної та позааудиторної діяльності, педагогічних практик 
(активної, пасивної), дослідницьких проектів і досліджень, самостійної роботи (виступи на конференціях, підготовка презентацій, наукових і творчих робіт, дослідження біографій відомих постатей) студентів художньо-педагогічних спеціальностей проблемним змістом, який актуалізує процеси самоаналізу та аналізу власної діяльності, iї оцінку та самооцінку.

Представлені нами вище результати теоретичного аналізу дають підстави стверджувати, що дослідницька компетентність $є$ динамічною комбінацією знань, вмінь i практичних навичок здійснення науково-дослідницької діяльності, способів мислення, професійних, світоглядних і морально-етичних цінностей, які визначають здатність студента успішно здійснювати професійну та подальшу освітню діяльність. Педагогічні умови іiі формування у студентів художньо-педагогічних спеціальностей при цьому визначаються її складовими, які нами згруповані у такі чотири блоки: система світоглядних і моральноетичних цінностей; динамічна комбінація знань, вмінь, практичних навичок i способів мислення; особистісні якості й фахові знання; самоаналіз та аналіз діяльності, самооцінка й оцінка її ефективності.

Висновки і перспективи подальших розвідок. Отже, теоретичний аналіз проблеми дослідницької компетентності студентів спеціальностей художньо-педагогічного факультету дав можливість виокремити іiі складові (мотиваційно-ціннісна, змістовно-процесуальна, професійна i рефлексивна складові), які задають групи відповідних педагогічних умов ефективного формування.

До педагогічних умов нами віднесено:

- цілеспрямоване формування мотиваційно-ціннісної спрямованості особистості на продуктивну і творчу діяльність дослідницького характеру, логіка розгортання якого реалізується у закладі вищої освіти з формування спершу мотивів та потреб майбутнього спеціаліста у сфері художньопедагогічної дії, а згодом трансформуються у систему ціннісного ставлення до науково-дослідницької діяльності як невід'ємної складової продуктивної професійної діяльності;

- змістово-процесуальне та технологічне забезпечення науководослідницької діяльності студентів, яке стимулює розвиток у них операційних, організаційні, практичних і комунікативних знань, умінь, практичних навичок $\mathrm{i}$ способів мислення в умовах впровадження спеціально сконструйованого навчального курсу, різноманітних форм та методів активної педагогічної взаємодії;

- організація цілеспрямованої продуктивної діяльності студентів 3 достатньо грунтовного оволодіння фаховими знаннями (диференціюються залежно від напряму мистецької діяльності і визначаються стандартами вищої освіти), у якій формуються необхідні для майбутньої професії особистісні якості (ініціативність, самостійність, відповідальність, наполегливість);

- створення інноваційно-рефлексивного середовища для формування особистісної і професійної рефлексії, яка спонукає до самоаналізу та аналізу професійної діяльності, самооцінки й оцінки ії ефективності.

Щодо перспектив подальших наукових розвідок 3 проблеми відносимо вивчення таких аспектів: впровадження ідей та принципів праксеології, застосування ефективних прийомів в процесі методичної підготовки майбутніх учителів предметників художньо-естетичного циклу. 


\section{СПИСОК ВИКОРИСТАНИХ ДЖЕРЕЛ:}

Головань, М та Яценко, В. (2012). Сутність та зміст поняття «дослідницька компетентність». Теорія та методика навчання фундаментальних дисииплін у вищій школі:збірник наукових праць НМетАУ. Вип. VII. с.55-62.

Балашова, С. (2000). Формування дослідницьких умінь у студентів педагогічного коледжу в процесі вивчення природознавчих дисииплін. Кандидат педагогічних наук. Інститут педагогіки і психології проф. освіти АПН України. 20c.

Рогозіна, О. (2007). Формування дослідницьких умінь у майбутніх учителів трудового навчання. Кандидат педагогічних наук. Національний педагогічний університет імені М. П. Драгоманова (Київ). 18 с.

Волинець, Ю. (2015). Формування дослідницької компетентності майбутніх вихователів дошкільних навчальних закладів. Zbior raportow naukowych. Warszawa. c. 103-108.

Проворова, Є. (2017) Обгрунтування і реалізація моделі методичної підготовки майбутнього вчителя музики в аспекті мистецької рефлексії. Вісник Житомирського державного університету імені Івана Франка. - Серія: „Педагогічні науки”. Вип. 2 (88). с. 224-230.

Марусинець, М. (2012). Рефлексія вчителя: успіх до професійного зростання. Перша вчителька. № 3/4. с. 90-93.

Парфентієва, I. (2010). Формування рефлексї у майбутніх учителів музики в прочесі вивчення украӥнської хорової духовної музики . Кандидат педагогічних наук. Національний педагогічний університет імені М. П. Драгоманова. 23 с.

\section{REFERENCES:}

Holovan, M ta Yatsenko, V. (2012). Sutnist ta zmist poniattia „doslidnytska kompetentnist". [The Essence and Content of the Concept of "Research Competence"]. Teoriia ta metodyka navchannia fundamentalnykh dystsyplin u vyshchii shkoli:zbirnyk naukovykh prats NMetAU. Vyp. VII. s.55-62. [in Ukrainian]

Balashova, S. (2000). Formuvannia doslidnytskykh umin u studentiv pedahohichnoho koledzhu $v$ protsesi vyvchennia pryrodoznavchykh dystsyplin. [Formation of Research Skills among Students of the Pedagogical College in the Process of Studying Natural Sciences Disciplines]. Kandydat pedahohichnykh nauk. Instytut pedahohiky i psykholohii prof. osvity APN Ukrainy. 20 s. [in Ukrainian]

Rohozina, O. (2007). Formuvannia doslidnytskykh umin u maibutnikh uchyteliv trudovoho navchannia. [Formation of Research Skills for Future Teachers of Labor Education]. Kandydat pedahohichnykh nauk. Natsionalnyi pedahohichnyi universytet imeni M. P. Drahomanova (Kyiv). 18 s. [in Ukrainian]

Volynets, Yu. (2015). Formuvannia doslidnytskoi kompetentnosti maibutnikh vykhovateliv doshkilnykh navchalnykh zakladiv. [Formation of Research Competence of Future Educators of Pre-school Educational Institutions]. Zbior raportow naukowych. Warszawa. s. 103-108. [in Ukrainian]

Provorova, Ye. (2017) Obgruntuvannia i realizatsiia modeli metodychnoi pidhotovky maibutnoho vchytelia muzyky v aspekti mystetskoi refleksii. [Substantiation and Realization of the Model of Methodical Preparation of the Future Teacher of Music in the Aspect of Artistic Reflection]. Visnyk Zhytomyrskoho derzhavnoho universytetu imeni Ivana Franka. - Seriia: "Pedahohichni nauky". Vyp. 2 (88). s. 224-230. [in Ukrainian]

Marusynets, M. (2012). Refleksiia vchytelia: uspikh do profesiinoho zrostannia. [Teacher's Reflection: Success in Professional Growth]. Persha vchytelka. No 3/4. s. 9093. [in Ukrainian]

Parfentiieva, I. (2010). Formuvannia refleksii u maibutnikh uchyteliv muzyky $v$ protsesi vyvchennia ukrainskoi khorovoi dukhovnoi muzyky. [Formation of Reflection on Future Music Teachers in the Process of Studying Ukrainian Choral Spiritual Music]. 
Kandydat pedahohichnykh nauk. Natsionalnyi pedahohichnyi universytet imeni M. P. Drahomanova. 23 s. [in Ukrainian]

\title{
PEDAGOGICAL CONDITIONS OF FORMATION OF RESEARCH COMPETENCE TO STUDENTS OF ARTISTIC PEDAGOGICAL FACULTY
}

\author{
Natalia Dzyubyshyna \\ Candidate of Pedagogical Sciences, Associate Professor, \\ Associate Professor, the Dean at the Artistic Pedagogical Faculty \\ Rivne State University of the Humanities, \\ Rivne, Ukraine \\ ORCID : 0000-0002-2704-8157 \\ e-mail: natalia_dziubyshyna@ukr.net
}

\begin{abstract}
The article deals with the problem of formation of research competewnce to students of artistic pedagogical faculty. The essence and significance of research competence are revealed, components of competence of research ompetence are allocated and their content is substantiated. The pedagogical conditions for increasing the effectiveness of the process of forming the research competence of future specialists in the arts and pedagogical specialties are singled out, such as: purposeful formation of the motivational and value orientation of the individual on the productive and creative activities of a research character, the logic of deployment of which is implemented in the institution of higher education in shaping the motives and needs of a future specialist in the field of artistic and pedagogical action, and subsequently transformed into a system of value attitude to research activity as an integral part of productive professional activity; content and procedural and technological support of students' research activities, which enables the development of their operational, organizational, practical and communicative knowledge, skills, practical skills and ways of thinking in the context of the introduction of a specially designed training course, various forms and methods of active pedagogical interaction; organization of purposeful productive activity of students with a sufficiently thorough mastery of professional knowledge (differentiated depending on the direction of artistic activity and are determined by the standards of higher education),in which the personal qualities (initiative, independence, responsibility, perseverance) that are necessary for the future profession are formed; creation of an innovative-reflexive environment for the formation of personal and professional reflection, which enables introspection and analysis of professional activity, self-evaluation and evaluation of its effectiveness.
\end{abstract}

Key words: research competence, components of research competence, pedagogical conditions, students of artistic pedagogical faculty.

Статття надійшла до редакиії 27.04.2019p. 